\title{
A National Survey on Myocarditis Associated With the 2009 Influenza A (H1N1) Pandemic in Japan
}

\author{
Akira Ukimura, MD; Tohru Izumi, MD; Akira Matsumori, MD; \\ Clinical Research Committee on Myocarditis Associated \\ with the 2009 Influenza A (H1N1) Pandemic in Japan organized \\ by the Japanese Circulation Society
}

\begin{abstract}
Background: An influenza pandemic occurred in 2009 and myocarditis associated with the 2009 influenza A (H1N1) pandemic was reported among hospitalized patients from August 2009.

Methods and Results: The Japanese Circulation Society organized the Clinical Research Committee on Myocarditis Associated with Influenza Pandemic A (H1N1) 2009 and called for a case report on myocarditis for a national survey. The diagnosis of myocarditis was performed using the Guidelines for the Diagnosis and Treatment of Myocarditis (JCS 2009). Fifteen patients were reported to the committee. Fulminant myocarditis developed in 10 patients. Mechanical circulatory support (intra-aortic balloon pumping (IABP) and/or percutaneous cardiopulmonary support (PCPS)) was used on all 10 patients, 8 of whom were rescued. Abnormalities on echocardiography and elevated cardiac enzymes were seen in most of the patients. Myocarditis was found by endomyocardial biopsy in 6 patients. Three patients had complications with pneumonia.
\end{abstract}

Conclusions: In reality, myocarditis associated with pandemic influenza A (H1N1) seemed to be more common in hospitalized patients, compared with previous seasonal influenza virus outbreaks. To avoid misdiagnosis of acute myocarditis associated with influenza pandemic A (H1N1) 2009, it is essential to determine the characteristic symptoms, signs, and laboratory findings of acute myocarditis during influenza pandemics. Mechanical circulatory support (IABP and/or PCPS) was required to rescue patients with fulminant myocarditis. (Circ J 2010; 74: 21932199)

Key Words: Influenza; Myocarditis; Pandemic

I nfluenza pandemics occur every 10 to 50 years, and the 2009 influenza A (H1N1) pandemic has been spreading worldwide since the first cases were identified in the USA and the United Mexican States in April 2009. ${ }^{1-6}$ Most people infected with the 2009 influenza A (H1N1) pandemic recovered without any sequelae, and hospitalizations were quite rare in Japan until June 2009.,5 However, some Japanese cases of myocarditis including fulminant myocarditis caused by the 2009 influenza A (H1N1) pandemic began to be reported in hospitalized patients from August 2009. ${ }^{6}$ Thus, a Japanese National Survey, to investigate what is going on in the real world around myocarditis associated with the 2009 influenza A (H1N1) pandemic, was initiated by the Japanese Circulation Society.

\section{Editorial p 2060}

Acute myocarditis is a potentially lethal disease, and the etiological agents of viral myocarditis are enteroviruses including coxsackieviruses, adenoviruses, parvoviruses, hepatitis $\mathrm{C}$ virus, human immunodeficiency virus, influenza, and others. ${ }^{7-13}$ Fulminant myocarditis causes severe hemodynamic dysfunction and requires high-dose catecholamine and mechanical circulatory support. Fulminant myocarditis caused by viral infection is an uncommon type of myocarditis. ${ }^{7-9}$ The frequency of myocardial involvement in influenza infection has varied and fulminant myocarditis associated with influenza infection is exceedingly rare as shown by previous papers, although this probability depends on low affinities

Received May 11, 2010; revised manuscript received May 30, 2010; accepted June 2, 2010; released online August 6, 2010 Time for primary review: 15 days

Department of General Internal Medicine, Osaka Medical College, Takatsuki (A.U.); Department of Internal Medicine, Kitasato University School of Medicine, Sagamihara (T.I.); Department of Cardiology, Tokyo Medical University, Tokyo (A.M.), Japan

Member of the Clinical Research Committee on Myocarditis Associated with the 2009 Influenza A (H1N1) Pandemic in Japan organized by the Japanese Circulation Society see Appendix.

Mailing address: Akira Ukimura, MD, Department of General Internal Medicine, Osaka Medical College, 2-7 Daigaku-machi, Takatsuki 569-8686, Japan. E-mail: in3011@poh.osaka-med.ac.jp

ISSN-1346-9843 doi:10.1253/circj.CJ-10-0452

All rights are reserved to the Japanese Circulation Society. For permissions, please e-mail: cj@j-circ.or.jp 


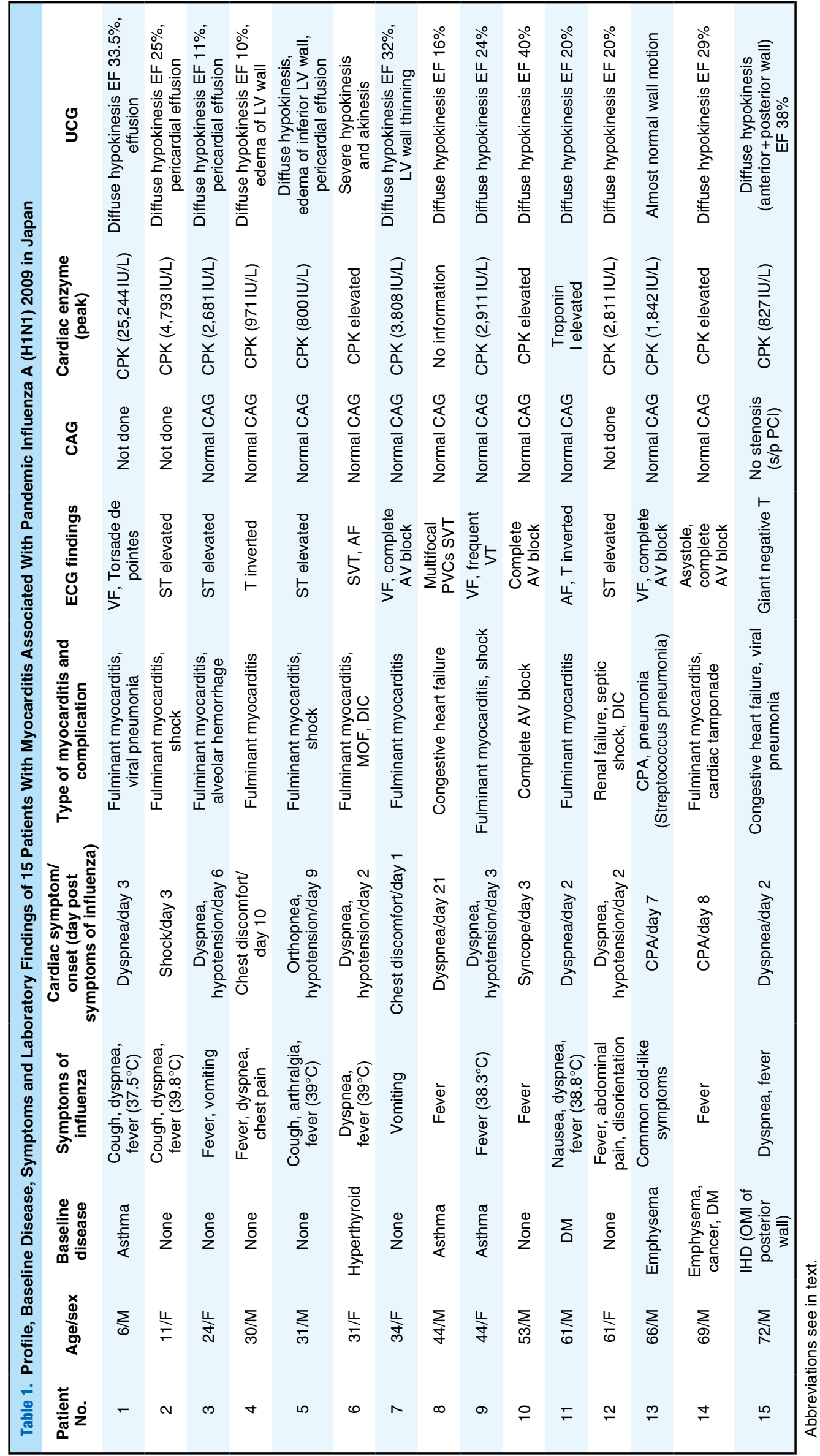




\begin{tabular}{|c|c|c|c|c|c|c|c|c|}
\hline $\begin{array}{l}\text { Patient } \\
\text { No. }\end{array}$ & $\begin{array}{l}\text { Agel } \\
\text { sex }\end{array}$ & $\begin{array}{l}\text { Rapid influenza } \\
\text { diagnostic testing }\end{array}$ & RT-PCR & $\begin{array}{l}\text { Ventilator/ } \\
\text { days }\end{array}$ & $\begin{array}{l}\text { Mechanical } \\
\text { support/days }\end{array}$ & Other treatment & $\begin{array}{l}\text { Biopsy or } \\
\text { autopsy }\end{array}$ & Outcome \\
\hline 1 & $6 / \mathrm{M}$ & Negative (day2,3) & $\begin{array}{c}2009 \mathrm{~A}(\mathrm{H} 1 \mathrm{~N} 1) \\
\text { (day 3) }\end{array}$ & $\begin{array}{l}\text { Used/ } \\
14 \text { days }\end{array}$ & PCPS/11days & $\begin{array}{l}\text { Steroid } 2 \mathrm{mg} / \mathrm{kg} \text {, } \\
\text { large amount } \\
\text { of } \gamma \text {-globulin }\end{array}$ & Not done & $\begin{array}{l}\text { Improved } \\
\text { (EF 63\%) }\end{array}$ \\
\hline 2 & $11 / \mathrm{F}$ & $\begin{array}{l}\text { Negative (day1) } \\
\rightarrow \text { positive (day3) }\end{array}$ & Not done & $\begin{array}{l}\text { Used/ } \\
22 \text { days }\end{array}$ & $\begin{array}{l}\text { PCPS/3days } \\
\text { IABP/4days }\end{array}$ & $\begin{array}{l}\text { Steroid pulse, } \\
\text { large amount } \\
\text { of } \gamma \text {-globulin }\end{array}$ & Not done & $\begin{array}{l}\text { Improved } \\
\text { (EF 70\%) }\end{array}$ \\
\hline 3 & $24 / F$ & Positive (day1) & Not done & Used & $\begin{array}{l}\text { PCPS/7days } \\
\text { IABP }\end{array}$ & $\begin{array}{c}\text { Usual dose } \\
\gamma \text {-globulin }\end{array}$ & Not done & $\begin{array}{l}\text { Improved } \\
\text { (EF 71\%) }\end{array}$ \\
\hline 4 & $30 / \mathrm{M}$ & $\begin{array}{l}\text { Negative (day1) } \\
\rightarrow \text { positive (day2) }\end{array}$ & $\begin{array}{l}\text { Negative } \\
\text { (day 20) }\end{array}$ & Not used & IABP/3days & Not used & Active myocarditis & Improved \\
\hline 5 & $31 / \mathrm{M}$ & Negative (day1) & $\begin{array}{c}\text { 2009A (H1N1) } \\
\text { (day 9) }\end{array}$ & Not used & IABP/3days & Not used & $\begin{array}{l}\text { Myocarditis } \\
\text { (mild) }\end{array}$ & Improved \\
\hline 6 & $31 / \mathrm{F}$ & Positive (day1) & $\begin{array}{c}\text { 2009A (H1N1) } \\
(\text { day 1) }\end{array}$ & $\begin{array}{l}\text { Used/ } \\
\text { 15days }\end{array}$ & $\begin{array}{l}\text { PCPS/7days } \\
\text { IABP/12days }\end{array}$ & $\begin{array}{c}\text { CHDF, } \\
\text { plasmapheresis }\end{array}$ & Myocarditis & Improved \\
\hline 7 & $34 / F$ & Negative (day1) & $\begin{array}{c}2009 \mathrm{~A}(\mathrm{H} 1 \mathrm{~N} 1) \\
\text { (day1) }\end{array}$ & $\begin{array}{l}\text { Used/ } \\
5 \text { days }\end{array}$ & $\begin{array}{l}\text { PCPS/4days } \\
\text { IABP/5days }\end{array}$ & Plasmapheresis & Not done & $\begin{array}{l}\text { Death on } \\
\text { day } 5\end{array}$ \\
\hline 8 & $44 / \mathrm{M}$ & Positive (day2) & $\begin{array}{c}\text { Not done } \\
(\mathrm{A} / \mathrm{CF} 32 \mathrm{X} \text { day45) }\end{array}$ & Not used & Not used & Not used & $\begin{array}{l}\text { Healing } \\
\text { myocarditis } \\
\text { (day 67) }\end{array}$ & $\begin{array}{l}\text { Incompletely } \\
\text { improved } \\
\text { (EF 25\%) }\end{array}$ \\
\hline 9 & $44 / F$ & Negative (day2) & $\begin{array}{c}\text { 2009A (H1N1) } \\
\text { (day 3) }\end{array}$ & Used & $\begin{array}{l}\text { PCPS/6days } \\
\text { IABP/12days }\end{array}$ & $\begin{array}{l}\text { Usual dose } \\
\gamma \text {-globulin }\end{array}$ & $\begin{array}{c}\text { Myocarditis } \\
\text { (day } 3 \text { and 24) }\end{array}$ & $\begin{array}{l}\text { Improved } \\
\text { (EF 60\%) }\end{array}$ \\
\hline 10 & $53 / \mathrm{M}$ & Positive (day 1 ) & 2009A (H1N1) & Not used & Not used & Pacemaker & Done & Improved \\
\hline 11 & $61 / \mathrm{M}$ & Positive & 2009A (H1N1) & Used & IABP & Not used & $\begin{array}{c}\text { Myocarditis } \\
\text { (day } 4 \text { and 10) } \\
\text { negative RT-PCR }\end{array}$ & Improved \\
\hline 12 & $61 / \mathrm{F}$ & Positive (day1) & Not done & Not used & Not used & $\begin{array}{l}\text { Usual dose- } \\
\text { globulin }\end{array}$ & Not done & $\begin{array}{l}\text { Improved } \\
\text { (EF 50\%) }\end{array}$ \\
\hline 13 & $66 / \mathrm{M}$ & Not done & $\begin{array}{c}\text { 2009A (H1N1) } \\
\text { (day7) }\end{array}$ & $\begin{array}{l}\text { Used/ } \\
4 \text { days }\end{array}$ & Not used & Not used & $\begin{array}{l}\text { Interstitial fibrosis } \\
\text { (day 31) }\end{array}$ & Improved \\
\hline 14 & $69 / \mathrm{M}$ & Positive (day1) & $\begin{array}{c}\text { 2009A (H1N1) } \\
\text { (day1) }\end{array}$ & $\begin{array}{l}\text { Used/ } \\
2 \text { days }\end{array}$ & PCPS/2days & Not used & $\begin{array}{l}\text { Interstitial fibrosis } \\
\text { (Autopsy) }\end{array}$ & $\begin{array}{l}\text { Death on } \\
\text { day } 9\end{array}$ \\
\hline 15 & $72 / \mathrm{M}$ & Positive (day2) & $\begin{array}{c}2009 \mathrm{~A}(\mathrm{H} 1 \mathrm{~N} 1) \\
\text { (day4) }\end{array}$ & BiPAP & Not used & $\begin{array}{l}\text { Usual dose } \\
\gamma \text {-globulin }\end{array}$ & $\begin{array}{l}\text { Interstitial fibrosis } \\
\text { (day 8) }\end{array}$ & $\begin{array}{l}\text { Incompletely } \\
\text { improved } \\
\text { (EF 44\%) }\end{array}$ \\
\hline
\end{tabular}

${ }^{\star} \mathrm{CF}$ titer to Influenza virus A was 1:32 on day 45 .

Abbreviations see in text.

to cardiac involvement of the influenza virus and/or the methods used to diagnose myocardial involvement and influenza infection. ${ }^{7-9}$ Although usually both the diagnosis and treatment of the pathogen involved in myocarditis are difficult, good diagnostic methods, such as influenza tests, which were quickly checked and reverse transcription polymerase chain reaction (RT-PCR) for the 2009 influenza A (H1N1) pandemic, and treatment with neuraminidase inhibitors were already available in this 2009 pandemic. ${ }^{1-6}$

\section{Methods}

To investigate what is going on in the real world around myocarditis associated with the 2009 influenza A (H1N1) pandemic, the task forces directed by the Japanese Circulation Society organized a Clinical Research Committee for Myocarditis associated with the pandemic. The Japanese Circulation Society called for a case report on myocarditis associated with the 2009 influenza A (H1N1) pandemic to all members $(24,203$ persons in total) from all regions of Japan through direct e-mail in November 2009. Fifteen cases were immediately reported to the task forces within 4 months, and all cases were analyzed. The diagnosis of myocarditis was performed using the Guidelines for the Diagnosis and Treatment of Myocarditis (JCS 2009). ${ }^{10}$ Compatible clinical symptoms, echocardiographic abnormalities in the absence of cardiac ischemia, leakage of cardiac enzymes and/or other evidence of myocardial damage provided the highly probable diagnosis for myocarditis. Myocardial biopsy or autopsy provided the histological diagnosis for myocarditis. Laboratory diagnosis of influenza pandemic A (H1N1) 2009 was made by quick influenza diagnostic testing and/or probe-based RT-PCR using a nasopharyngeal swab or sputum.

\section{Results}

Fifteen patients ( 9 men and 6 women, mean age $42.4 \pm 20.8$ years) were reported to the task force of the Clinical Research for Myocarditis associated with the 2009 influenza A (H1N1) pandemic. They were admitted to hospitals from August 2009 to February 2010. The profiles, baseline disease, symptoms and laboratory findings of these 15 patients are shown in Table 1, and the results of diagnostic tests for influenza infection, treatment, histological findings and outcome in Table 2. Myocarditis was proven by endomyocardial biopsy in 6 patients, and myocarditis was clinically diagnosed based on clinical figures, leakage of cardiac enzymes, abnormalities on echocardiography, and other findings in the other 9 patients. ${ }^{10}$ History was useful in obtaining the correct diagnosis. Thirteen patients complained of typical symptoms of 


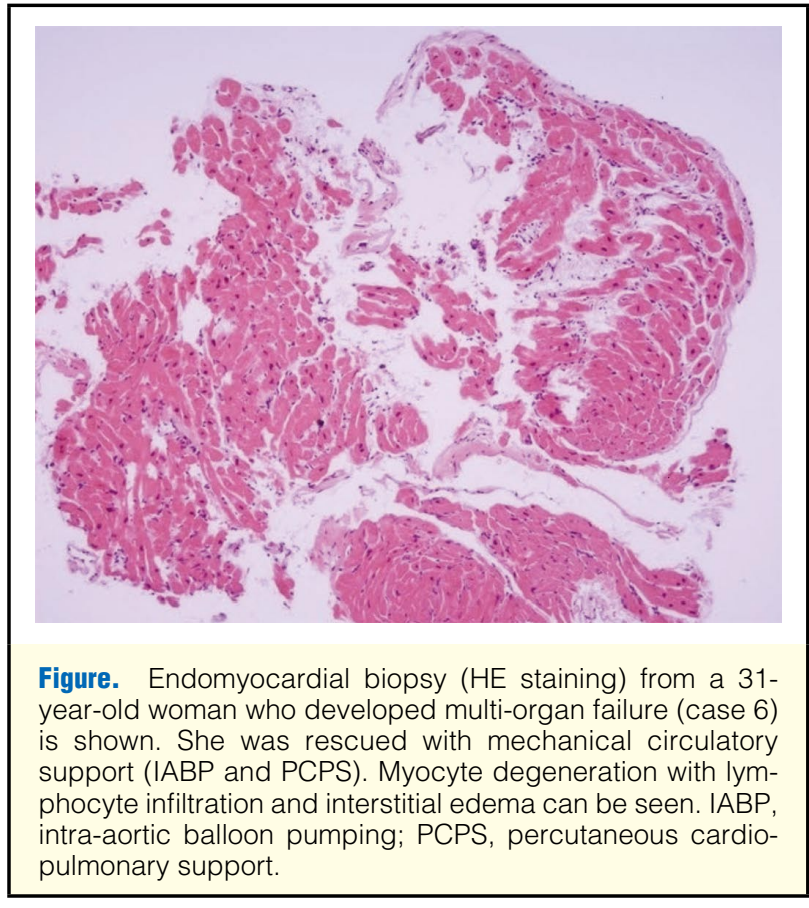

influenza, such as high fever, cough, headache, and arthralgia. Three patients (20\%) complained of abdominal symptoms (abdominal pain, nausea, and vomiting), and one patient complained of common cold-like symptoms. Cardiac symptoms such as dyspnea, chest discomfort, hypotension and syncope developed on the $2^{\text {nd }}-21^{\text {st }}$ day of sickness. The most frequent baseline disease was a respiratory disorder in $5(33 \%)$ patients (bronchial asthma in 3 patients and emphysema in 2 patients), and others were diabetes in 1 patient and ischemic heart disease in 1 patient. Three patients with myocarditis were complicated by pneumonia: viral pneumonia in 2 patients and bacterial pneumonia in 1 patient.

Most patients exhibited electrocardiogram (ECG) abnormalities, including ventricular fibrillation in 3 patients, complete AV block in 4 patients, ST elevation in 4 patients, giant negative $\mathrm{T}$-waves in 1 patient, and atrial fibrillation in 1 patient. Two patients were emergently admitted because of cardiopulmonary arrest due to ventricular fibrillation or complete AV block. Echocardiography revealed abnormalities of left ventricular wall motion in 14 patients and pericardial effusion in 2 patients. Cardiac dysfunction almost completely recovered in 11 patients but only incompletely in 2 patients. Coronary angiography was performed on 12 patients, which yielded normal results in all. Cardiac enzymes were elevated in 14 patients, with a peak serum creatine kinase concentration of 800 to 25,244 (IU/L). Quantitative troponin testing was measured in 4 patients and was found to be elevated in all patients. Qualitative quick troponin testing was measured in 3 patients, and was positive in 1 patient.

The clinical manifestations of myocarditis caused by influenza pandemic $A(\mathrm{H} 1 \mathrm{~N} 1)$ varied greatly, and 10 patients were diagnosed with fulminant myocarditis with fatal arrhythmias, and/or varying degrees of cardiogenic shock. Cardiopulmonary arrest was the first cardiac symptom in 2 patients. Syncope due to complete AV block was the first cardiac symptom in 1 patient, who was rescued with temporary pacemaker implantation. The clinical course of patients also varied. Cardiac dysfunction progressed rapidly in 12 patients;
10 of these $(83 \%)$ recovered to their previous condition and 2 died. Cardiac dysfunction developed after recovery from flu-like symptoms in 2 patients, and myocarditis appeared to have persisted for 1.5 months in 1 patient.

Quick diagnostic testing for influenza, performed on the first visit to the clinic, was negative in 5 patients and positive in 8 patients. ${ }^{4-6}$ Quick diagnostic testing, when performed a second time was positive in 2 patients who initially had negative results. RT-PCR testing for the 2009 influenza A (H1N1) pandemic yielded positive results in 10 patients. RT-PCR or quick diagnostic testing yielded positive results in all patients.

Endomyocardial biopsy was performed in 8 patients and an autopsy was performed in 1 patient. Endomyocardial biopsies demonstrated histological myocarditis in 6 patients. Histological findings of an endomyocardial biopsy from case 6 , who developed multi-organ failure, are shown in Figure. She was rescued with mechanical circulatory support. Lymphocyte infiltration and interstitial edema could be seen. RT-PCR testing for pandemic influenza A (H1N1) from a biopsy specimen was performed only in 1 case, but it was negative.

A ventilator was used in 6 patients and a biphasic positive airway pressure support system (BIPAP) was used in 1 patient. Mechanical circulatory support with intra-aortic balloon pumping (IABP) and/or percutaneous cardiopulmonary support (PCPS) was emergently inserted in 9 patients. Seven patients were rescued with mechanical circulatory support, and 2 patients died. A temporary pacemaker was implanted into the patient with complete AV block. All patients were treated with neuraminidase inhibitors, and high-dose immunoglobulin was used in 2 patients. Corticosteroid was used only in 2 children, but not in any adult patients.

\section{Discussion}

The influenza pandemic began in Kobe and Osaka, the middle region of Japan, in May 2009, and all patients recovered until July 2009 without any sequelae., ${ }^{4,5}$ It was reported that, in Canada, critical illness due to the 2009 influenza A (H1N1) pandemic occurred rapidly after hospital admission, often in young adults, and was associated with severe hypoxemia, multisystem organ failure, which necessitated prolonged mechanical ventilation, and the frequent use of rescue therapy. ${ }^{1-3}$ Hospitalization and death caused by the 2009 influenza A (H1N1) pandemic increased from August 2009, but this was rare in Japan. The Ministry of Health, Labor and Welfare (MHLW) of Japan confirmed only 85 deaths by $1^{\text {st }}$ December 1,2009 , although the estimated number of cases was about 12.6 million by the end of November. ${ }^{6}$ Japanese data obtained from the MHLW website showed that the proportion of influenza-like illness cases in those aged $0-4$ years and in adults was lower in Japan, compared with other countries. More than $75 \%$ of cases were those aged 5-19 years with a low rate of fatalities in Japan. The mortality rates, both per reported rates and per hospitalizations, increased significantly with age. The mean age of the 15 myocarditis cases associated with the 2009 influenza A (H1N1) pandemic was 42 years, which was higher than the mean of estimated cases and similar to other fatal cases during the pandemic in Japan. ${ }^{6}$

Acute myocarditis is a potentially lethal disease, and the etiological agents of viral myocarditis are enteroviruses including coxsackieviruses, adenoviruses, parvoviruses, hepatitis $\mathrm{C}$ virus, human immunodeficiency virus, influenza, and others. ${ }^{7-10}$ Coxsackievirus $\mathrm{B}$ has been described as the most common pathogen of viral myocarditis, and hepatitis $C$ virus is associated with many different forms of heart disease world- 
wide, however, influenza myocarditis is relatively rare. ${ }^{11-16}$ Bratinssak et al reported four fulminant myocarditis cases in patients aged from 3 to 9 associated with the 2009 influenza A (H1N1) pandemic within a 30-day period, and this suggested that the 2009 influenza A (H1N1) pandemic was more commonly associated with myocarditis than seasonal influenza. ${ }^{14}$ Martin et al identified 6 patients with reversible cardiac dysfunction associated with pandemic influenza A (H1N1) out of 123 hospitalized pandemic influenza A (H1N1) patients. ${ }^{15}$ There was only 1 case report of fulminant myocarditis with the 2009 influenza A (H1N1) pandemic in Europe. ${ }^{16}$ We report herein 15 myocarditis patients varying in age from a child to an old man over 70 -year-old as a result of cross-sectional national survey by assist from all members of the Japanese Circulation Society using direct e-mailing system. We suggest that myocarditis is, along with pneumonia and encephalopathy, an important cause of clinical deterioration in influenza patients in Japan. Myocarditis associated with the 2009 influenza A (H1N1) pandemic seemed to be more common in hospitalized patients, compared with previous seasonal influenza virus. ${ }^{6}$

The diagnosis of myocarditis was performed using the Guidelines for the Diagnosis and Treatment of Myocarditis (JCS 2009) with a hybrid of compatible clinical symptoms, evidence of cardiac dysfunction, abnormality of cardiac enzymes in the absence of active coronary ischemia or other evidence of myocardial damage. ${ }^{10}$ Clinical symptoms of these patients were not specific; however, most patients complained of not only upper respiratory symptoms but also systemic symptoms. ST elevation was seen in 4 patients and giant negative T-wave was seen in 1 patient, so ECG findings were not specific. Echocardiography revealed reversible abnormalities of left ventricular wall motion, and cardiac enzymes were elevated in most patients. Quantitative troponin was measured in 4 patients and elevated in all; however, qualitative quick troponin testing was measured in 3 patients, but was positive in only 1 patient in this study. Reichlin et al reported that sensitive cardiac troponin assays improve the early diagnosis of myocardial infarction, so we recommend that these assays might be useful for the diagnosis and management of myocarditis. ${ }^{17}$ Cardiac scintigram is also useful. ${ }^{10,18,19}$ A new approach to diagnose myocarditis is cardiovascular magnetic resonance (CMR) imaging. ${ }^{10}$ Liu and Yan observed that CMR imaging is helpful for the detection of myocarditis, because CMR can visualize the entire myocardium. ${ }^{18} \mathrm{CMR}$ probably has good sensitivity in detecting patchy processes and changes in tissue composition associated with inflammation. To avoid misdiagnosis of acute myocarditis as a complication of influenza infection, it is essential to determine the characteristic symptoms, signs, and laboratory findings of acute myocarditis during influenza infection. Myocarditis is probably underdiagnosed, so we have to strongly suspect myocarditis in hospitalized patients during an influenza pandemic.

Influenza is an acute respiratory illness caused by infection with influenza viruses. The most frequent baseline disease in the present study was lung disease, in $5(33 \%)$ patients (asthma in 3 patients and emphysema in 2 patients). RT-PCR assays or quick diagnostic testing yielded positive results in 15 patients, and viral pneumonia were complicated in 2 patients in this study. Nasopharyngeal smears or sputum were positive for influenza pandemic A (H1N1) 2009 virus on RT-PCR assay in 10 patients. RT-PCR assay was not performed or was negative, and further characterization of the virus was not performed in the other 5 patients. However, pandemic influenza A (H1N1) infection was strongly suspected, because it was previously revealed that over $99 \%$ of influenza A positive samples were identified with pandemic influenza A (H1N1) during this period by RT-PCR analysis. Although quick diagnostic testing for influenza is usually performed in Japan, the sensitivity of this type of testing is not high enough. ${ }^{4-6}$ Quick diagnostic testing for influenza, which was performed at the first visit to the clinic, was negative in 5 patients. One child who was hospitalized in the Osaka Medical College Hospital under the diagnosis of viral pneumonia caused by pandemic influenza A (H1N1) was found to be positive for viral pneumonia based on the chest $\mathrm{X}$-ray, accumulated white blood cell counts in the absence of bacterial infection, high serum $\mathrm{C}$-reactive protein concentrations and negative quick diagnostic testing for influenza on the 2nd day of sickness. Itoh et al reported that the 2009 influenza A (H1N1) pandemic caused more severe pathological lesions in the lungs of infected mice, ferrets, and non-human primates than the seasonal human $\mathrm{H} 1 \mathrm{~N} 1$ virus. $^{20}$ Nakajima et al reported that the concentrations of various cytokines/chemokines in the serum and autopsied lung tissue were elevated in both of the first autopsy cases in Japan. ${ }^{21}$ Muneuchi et al reported that myocarditis associated with influenza B virus appeared to be caused by endothelial impairment and disturbance of microcirculation rather than direct injury to cardiac myocytes. ${ }^{22}$ These findings suggest that a negative quick diagnostic test of patients with systemic symptoms might lead to hospitalization due to symptomatic viral pneumonia, or myocarditis, and the pathogenesis of systemic complications of influenza might be related to the induction of inflammatory cytokines produced by infected alveolar cells.

The clinical manifestations of myocarditis quite varied. Cardiac dysfunction progressed rapidly in 12 patients, and cardiac dysfunction developed after recovery from flu-like symptoms in 2 patients, and probably persisted for 1-1.5 months in 1 patient. Cases including slow progressive myocarditis and repetitive myocarditis are very rare. Takehana et al reported that a 75-year-old man who recovered from myocarditis associated with influenza A developed cardiogenic shock and died of fulminant myocarditis. ${ }^{23}$ Most patients who survived recovered without any cardiac sequelae in this study, quite similar to previous reports. The degree of myocarditis associated with the 2009 influenza A (H1N1) pandemic was in the present study relatively mild even in patients with fulminant myocarditis. ${ }^{24}$ Kotaka et al reported that murine influenza myocarditis was histologically mild and brief in duration compared to coxsackievirus B3 myocarditis. ${ }^{25}$ We suggest that the pathogenesis and pathomechanism of pandemic influenza myocarditis differ depending on the pathogen, ${ }^{25}$ and moreover, that significant mechanisms of cardiac injury, such as cytokine storm, endothelial dysfunction, oxidative stress and other factors, might play significant roles in the pathogenesis of pandemic influenza myocarditis. ${ }^{21-27}$ RT-PCR testing for pandemic influenza A (H1N1) from biopsy specimens was performed in only 1 case, and was negative. To evaluate influenza viral persistence in the myocardium in cases with myocarditis, further evaluation of viral replication in the myocardium using RT-PCR or in situ hybridization methods for pandemic influenza A (H1N1) from myocardial specimens is inevitable.

The first therapy for myocarditis patients with heart failure is supportive intervention. The recent application of PCPS and/or IABP to serious cases of viral myocarditis has yielded good outcomes..$^{5,29}$ The severity and grade of cardiac and renal 
dysfunction are important factors in connection with the prognosis. In this study, 8 patients were rescued using mechanical circulatory support and 2 patients died. It is important to recognize that patients with influenza infection might have acute myocarditis with heart failure, and that early diagnosis is required for adequate treatment.

Neuraminidase inhibitors work by blocking the function of the viral neuraminidase protein and thus prevent the virus from reproducing by budding from the host cell, and are useful for treating and preventing influenza virus infections. ${ }^{1-6,20}$ Itoh et al reported that the 2009 influenza A (H1N1) pandemic is sensitive to neuraminidase inhibitors, suggesting that these drugs could function as a first line of defense against the 2009 influenza A (H1N1) pandemic. ${ }^{1-6,20}$ Treatment with neuraminidase is also recommended by the Japanese Association of Infection. The low rate of case fatality in Japan could be a result of aggressive early intervention using with antiviral drugs such as oseltamivir and zanamivir. All of the present patients were treated with oseltamivir. In Japan, 3 types of neuraminidase inhibitors are available: oseltamivir, zanamivir, and peramivir. Adamantine, a M2 protein blocker, is resistant to the 2009 influenza A (H1N1) pandemic, while oseltamivir and zanamivir exhibit lower frequencies of antiviral resistance..$^{29}$ Oseltamivir is orally available, while zanamivir is inhaled. ${ }^{25}$ Halvala et al identified 10 patients who developed the $\mathrm{H} 275 \mathrm{Y}$ oseltamivir-resistance mutation out of 1,802 samples in Scotland..$^{30}$ The new neuraminidase inhibitor, peramivir, is formulated for intravenous administration and it has resulted in a good IC50 response for pandemic influenza virus. Peramivir is recommended for patients requiring ventilation with difficulty in absorption of osertamivir. ${ }^{29}$ Treatment with high-dose immunoglobulin was used in 2 patients, which is still controversial. ${ }^{31}$ Corticosteroid was used only in 2 children, but not in adult patients. We know that inflammatory cytokines are important in the infection course of influenza; however, immunosuppression therapy with corticosteroids is not recommended, and this is supported by previous evidence., ${ }^{2,10}$ Moderate- to high-dose steroids are not recommended by the World Health Organization, because they are of unproven benefit and potentially harmful.

\section{Conclusion}

As a result of the present national survey in Japan, myocarditis associated with the 2009 influenza A (H1N1) pandemic seemed to be more common, compared with previous seasonal influenza viruses. To avoid misdiagnosis of acute myocarditis caused by influenza pandemic A (H1N1) 2009, the characteristic symptoms, signs, and laboratory findings of acute myocarditis during influenza pandemics must be determined. Mechanical circulatory support (IABP and or PCPS) was required to rescue myocarditis patients by all means. Appropriate treatment using neuraminidase inhibitors must be recommended for patients with myocarditis associated with the influenza A (H1N1) pandemic.

\section{Acknowledgement}

This study was supported in part by a research grant for intractable diseases from the Ministry of Health, Labor and Welfare and grants-in-aid from the Japanese Ministry of Education, Culture, Sports, Science and Technology, Tokyo, Japan.

\section{References}

1. Centers for Disease Control and Prevention (CDC). Patients hospitalized with 2009 pandemic influenza A (H1N1)-New York City,
May 2009. MMWR Morb Mortal Wkly Rep 2010; 58: 1436-1440.

2. Kumar A, Zarychanski R, Pinto R, Cook DJ, Marshall J, Lacroix J, et al; Canadian Critical Care Trials Group H1N1 Collaborative. Critically ill patients with 2009 influenza A(H1N1) infection in Canada. JAMA 2009; 302: 1872-1879.

3. WHO. Clinical management of human infection with new influenza A (H1N1) virus: Initial guidance. Geneva, WHO, 21 May 2009.

4. Kawaguchi R, Miyazono M, Noda T, Takayama Y, Sasai Y, Iso H. Influenza (H1N1) 2009 outbreak and school closure, Osaka Prefecture, Japan. Emerg Infect Dis 2009; 15: 1685.

5. Shimada T, Gu Y, Kamiya H, Kojima N, Odaira F, Sunagawa T, et al. Epidemiology of influenza A(H1N1) virus infection in Japan, May-June 2009. Eurosurvailance 2009; 14: 1-3.

6. Kamigaki T, Oshitani H. Epidemiological characteristics and low case fatality rate of pandemic (H1N1) 2009 in Japan. PLoS Curr Influenza 2009; 20: RRN1139.

7. Aoyama N, Izumi T, Hiramori K, Isobe M, Kawana M, Hiroe M, et al. National survey of fulminant myocarditis in Japan: Therapeutic guidelines and long-term prognosis of using percutaneous cardiopulmonary support for fulminant myocarditis (special report from a scientific committee). Circ J 2002; 66: 133-144.

8. Mamas MA, Fraser D, Neyses L. Cardiovascular manifestations associated with influenza virus infection. Int J Cardiol 2008; 130: 304-309.

9. Sekiguchi M, Hiroe M, Hiramitsu N. Natural history of acute viral or idiopathic myocarditis: A clinical and endomyocardial biopsy follow-up. In: Schultheiss HP, editor. New concepts of viral heart disease. Berlin: Springer-Verlag, 1988; 33-50.

10. Izumi T, Isobe M, Kawai $\mathrm{Y}$, Kawana M, Kimura K, Kyo S, et al. Guidelines for Diagnosis and Treatment of Myocarditis (JCS 2009). Circ J 2009; http://www.j-circ.or.jp/guideline/pdf/JCS2009_izumi_ h.pdf (accessed 25 November, 2009).

11. Tam P. Coxsackevirus myocarditis: Interplay between virus and host in the pathogenesis of heart disease. Viral Immunol 2006; 19: $133-146$.

12. Koide H, Kitaura Y, Deguchi H, Ukimura A, Kawamura K, Hirai $\mathrm{K}$. Genomic detection of enteroviruses in the myocardium-studies on animal hearts with coxsackievirus B3 myocarditis and endomyocardial biopsies from patients with myocarditis and dilated cardiomyopathy. Jpn Circ J 1992; 56: 1081-1093.

13. Matsumori A. Global alert and response network for hepatitis $\mathrm{C}$ virus-derived heart diseases: A call to action. CVD Prevent Control 2009; 4: 109-118.

14. Bratincsák A, El-Said HG, Bradley JS, Shayan K, Grossfeld PD, Cannavino CR. Fulminant myocarditis associated with pandemic H1N1 influenza A virus in children. J Am Coll Cardiol 2010; 55: 928-929.

15. Matrin SS, Hollingworth CL, Norfolk SG, Wolfe CR, Hollingworth JW. Reversible cardiac dysfunction associated with pandemic2009-H1N1 Influenza A. Chest 2010; 137: 1195-1197.

16. Weiss TW, Knut H, Stensaeth KH, Eritsland J. Myocarditis in a juvenile patient with influenza A virus infection. Eur Heart J 2010; 31: 277.

17. Reichlin T, Hochholzer W, Bassetti S, Steuer S, Stelzig C, Hartwiger $\mathrm{S}$, et al. Early diagnosis of myocardial infarction with sensitive cardiac troponin assays. N Engl J Med 2009; 361: 858-867.

18. Liu PP, Yan AT. Cardiovascular magnetic resonance for the diagnosis of acute myocarditis: Prospects for detecting myocardial inflammation. J Am Coll Cardiol 2005; 45: 1823-1825.

19. Bella GD, Gaeta M, Pingitore A, Oreto G, Zito C, Minutoli F, et al. Myocardial deformation in acute myocarditis with normal left ventricular wall motion. Circ J 2010; 74: 1205-1213.

20. Itoh Y, Shinya K, Kiso M, Watanabe T, Sakoda Y, Hatta M, et al. In vitro and in vivo characterization of new swine-origin H1N1 influenza viruses. Nature 2009; 460: 1021-1025.

21. Nakajima N, Hata S, Sato Y, Tobiume M, Katano H, Kaneko K, et al. The first autopsy case of pandemic influenza (A/H1N1pdm) virus infection in Japan: Detection of a high copy number of the virus in type II alveolar epithelial cells by pathological and virological examination. Jpn J Infect Dis 2010; 631: 67-71.

22. Muneuchi J, Kanaya Y, Takimoto T, Hoshina T, Kusuhara K, Hara $\mathrm{T}$. Myocarditis mimicking acute coronary syndrome following influenza B virus infection: A case report. Cases J 2009; 2: 6809.

23. Takehana H, Inomata T, Kuwao S, Nakahata J, Sasaki T, Nishii M, et al. Recurrent fulminant viral myocarditis with a short clinical course. Circ J 2003; 67: 646-648.

24. Hiramitsu S, Morimoto S, Kato S, Uemura A, Ohtsuki M, Kato Y, et al. Clinical course of myocarditis through the acute, fulminant and fatal chronic stages: An autopsy case. Circ J 2006; 70: 10861090. 
25. Kotaka M, Kitaura Y, Deguchi H, Kawamura K. Experimental influenza A virus myocarditis in mice: Light and electron microscopic, virologic, and hemodynamic study. Am J Pathol 1990; 136: $409-419$.

26. To KK, Hung IF, Li IW, Lee KL, Koo CK, Yan WW, et al. Delayed clearance of viral load and marked cytokine activation in severe cases of pandemic H1N1 2009 influenza virus infection. Clin Infect Dis 2010; 50: 850-859.

27. Yoshikawa T, Baba A, Nagatomo Y. Autoimmune mechanisms underlying dilated cardiomyopathy. Circ J 2009; 73: 602-607.

28. Montcriol A, Wiramus S, Ribeiri A, Attard N, Nait-Saidi L, Kerbaul F, et al. Successful management of Influenza A associated fulminant myocarditis: Mobile circulatory support in intensive care unit: A case report. Cases $J$ 2008; 1: 46.

29. Centers for Disease Control and Prevention (CDC). Update: Drug susceptibility of swine-origin influenza A (H1N1) viruses, April 2009. MMWR Morb Mortal Wkly Rep 2009; 58: 433-435.

30. Harvala H, Fuston R, Simmonds P, Hardie A, Bennett S, Scott F, et al. The emergence of osertamivir-resistanct pandemic influenza A (H1N1) 2009 amongst hospitalized immunocompromised patients in Scotland, November-December, 2009. http://www.ewrosuvaillncw. org (accessed 8 April, 2010).

31. Kato S, Morimoto S, Hiramitsu S, Uemura A, Ohtsuki M, Kato Y, et al. Successful high-dose intravenous immunoglobulin therapy for a patient with fulminant myocarditis. Heart Vessels 2007; 22: 48-51.

\section{Appendix}

Members of the Clinical Research Committee on Myocarditis Associated with Pandemic 2009 H1N1 in Japan organized by the Japanese Circulation Society

Tohru Izumi, MD (Department of Internal Medicine, Kitasato University
School of Medicine, Sagamihara, Japan)

Akira Matsumori, MD (Department of Cardiology, Tokyo Medical University, Tokyo, Japan)

Akira Ukimura, MD (Department of General Internal Medicine, Osaka Medical College, Takatsuki, Japan)

Makiko Nakamura, MD (Okinawa Prefectural Nanbu Medical Center, Okinawa, Japan)

Kenji Nishioka, MD (Department of Medicine and Molecular Science, Hiroshima University Graduate School of Biomedical Sciences, Hiroshima, Japan)

Eri Kanai, MD (Department of Cardiovascular Medicine, Kyoto Prefectural University School of Medicine, Kyoto, Japan)

Toshiaki Jibiki, MD (Department of Pediatrics, Chiba Kaihin Municipal Hospital, Chiba, Japan)

Nobuaki Shikama, MD (Chiba Aoba Municipal Hospital, Chiba, Japan) Ryuta Imaki, MD; Ichiro Takeuchi, MD (Department of Internal Medicine, Kitasato University School of Medicine, Sagamihara, Japan)

Tomohiko Iwata, MD; Tsugiyoshi Yamazaki, MD (Department of Cardiology, Kawasaki Saiwai Hospital, Kawasaki, Japan)

Takahito Sone, MD (Department of Hypertension and Cardiorenal Medicine, Dokkyo Medical University, Mibu, Japan)

Hiroshi Takeshima, MD (Division of Cardiology, Tokyo Metropolitan Hiroo Hospital, Tokyo, Japan)

Yasuhiro Tanabe, MD (Tohoku University Hospital Emergency Center, Sendai, Japan)

Tomoyuki Endo, MD; Yosuke Inoue, MD (Kasugai Municipal Hospital, Kasugai, Japan)

Tomonori Amano, MD (Department of Cardiology, Uji Tokushukai Hospital, Uji, Japan)

Noriaki Takama, MD; Takashi Nagasaka, MD (Division of Cardiology, Isesaki Municipal Hospital, Isesaki, Japan) 